\title{
GINKGOLIDE B PROMOTES PROLIFERATION AND FUNCTIONAL ACTIVITIES OF BONE MARROW-DERIVED ENDOTHELIAL PROGENITOR CELLS: INVOLVEMENT OF AKT/ENOS AND MAPK/P38 SIGNALING PATHWAYS
}

\author{
Yubo Tang ${ }^{1,3,}$, Baoding Huang ${ }^{2,3, \S}$, Laibao $\mathrm{Sun}^{3}$, Xinsheng Peng ${ }^{2}$, Xiao Chen ${ }^{1, *}$ and Xuenong Zou ${ }^{2,3, *}$ \\ ${ }^{1}$ Department of Pharmacy, ${ }^{2}$ Department of Spine Surgery, \\ ${ }^{3}$ Orthopaedic Research Institute, The First Affiliated Hospital of Sun Yat-sen University, \\ Guangzhou, PR China
}

${ }^{\S}$ These two authors contributed equally to this work.

\begin{abstract}
Bone marrow-derived, circulating endothelial progenitor cells (EPCs) contribute to neovascularization in various diseases, and represent a very interesting alternative cell source for enhancing vasculogenesis in regenerative medicine. In this study, we investigated the effects of Ginkgolide B (GB) on proliferation and differentiation of EPCs, and the involved signaling pathway in vitro. EPC proliferation, migration, adhesion and angiogenesis activities were assessed with the WST-8 assay, Transwell chamber assay, cell counting and angiogenesis kit, respectively. Apoptosis was detected with annexin $\mathrm{V}$ and propidium iodide staining. The protein expression of angiogenesis-related makers was detected by Western blot, and related gene expression was determined by real-time polymerase chain reaction (RT-PCR). The results showed that GB promoted the proliferation and endothelial gene expression, and markedly enhanced vascular endothelial growth factor-induced migration response and the capability to incorporate into the vascular networks in EPCs. GB protected EPCs from $\mathrm{H}_{2} \mathrm{O}_{2}$-induced cell death. GB induced the phosphorylation of eNOS, Akt and p38, which in turn promoted cell proliferation and function. In conclusion, the present study demonstrates that GB, at a near medical applied dose, increases the number and functional activities of EPCs with involvement of Akt/endothelial nitric oxide synthase and mitogen-activated protein kinase (MAPK)/ p38 signal pathways. These findings raise the intriguing possibility that GB may play an important role in the protection and revascularization of blood vessels.
\end{abstract}

Keywords: Endothelial progenitor cells, Ginkgolide B, proliferation, angiogenesis, Akt, endothelial nitric oxide synthase (eNOS), p38.

*Address for correspondence:

Xuenong Zou

Department of Spine Surgery/Orthopaedic

Research Institute,

The First Affiliated Hospital of Sun Yat-sen University, 510080, Guangzhou, PR China

Xiao Chen, same address

E-mail: zxnong@hotmail.com

E-mail: frankwychen@yahoo.com

\section{Introduction}

It is well known that circulating endothelial progenitor cells (EPCs) play important roles in maintaining vascular integrity and in injury repair. EPCs are a type of cell population that have the capacity to circulate, proliferate and differentiate into mature endothelial cells, but have not yet acquired characteristic mature endothelial cell markers and have not yet formed a lumen (Asahara et al., 1997; Peichev et al., 2000).

There was compelling evidence for bone marrow (BM)-derived EPCs to play a pivotal role in the postnatal vasculogenesis (Dimmeler et al., 2001; Sata, 2006). Circulating progenitor cells derived from the bone marrow were found to exhibit features of endothelial cells, ability to home to sites of ischemia, and contribute to form new blood vessels (Isner and Asahara, 1999; Carmeliet, 2000). Mobilization of EPCs augmented the neovascularization of ischemic tissue and represented a useful therapeutic strategy for clinical therapy (Asahara et al., 1997; Satoshi and Takayuki, 2005). Growth factors (such as VEGF, PDGF, Ang-1, and stromal-derived factor-1) induced the mobilization and expansion of EPCs and hematopoietic stem cell populations in the bone marrow (Rabbany et al., 2003), which are through direct activation of signaling receptors on various subsets of precursor cells and paracrine interactions with the bone marrow stromal cells.

The extracts from the medicinal plant, Ginkgo biloba, act as antioxidant and free radical scavenger, and have been shown to exhibit protective effects on tissue abnormalities that include myocardial ischemiareperfusion injury (Shen et al., 1998), ischemic brain damage (Zhang et al., 2000), and neuronal apoptosis (Ahlemeyer et al., 1999). These effects are supposed to be beneficial in cardiovascular, cerebrovascular, and neurological disorders (Yoshikawa et al., 1999). The extracts of Ginkgo biloba mainly contain flavonoid glycosides and terpenoids (ginkgolide, bilobalide) . Ginkgolides have been demonstrated to function as antagonists of platelet-activating factor (Lamant et al., 1987), exhibit a wide range of pharmacological actions, such as inhibiting the aggregation of platelet (Akiba et al., 1998), arterial thrombosis (Bourgain et al., 1987), acute inflammation (Teather et al., 2002), allergic reaction (Coyle et al., 1989) and so on. Ginkgolides in the terpeniod extracts can be divided into isotypes A, B, C, M, and J among which Ginkgolide B (GB) $\left(\mathrm{C}_{20} \mathrm{H}_{24} \mathrm{O}_{10}\right)$ has the highest biological activity (Li et al., 2009). 
Mobilization of EPCs or mononuclear cells containing EPCs from bone marrow contribute to postnatal neovascularization via vasculogenesis and to increase functional blood supply (Kureishi et al., 2000). In addition, clinical studies reported that with the increase of age, accumulation of risk factors led to a decreased number of circulating EPCs, impaired cell activities and accelerated senescence (Scheubel et al., 2003; Chang et al., 2010; Takahisa et al., 2010). To overcome this problem, attention has increasingly been paid to enhance mobilization and differentiation of EPCs. GB was found to protect endothelial cells ( $\mathrm{Li}$ et al., 2009). Therefore, we hypothesized that GB may promote proliferation and functional activities of bone marrow-derived endothelial progenitor cells. In this study, we investigated the effects of $\mathrm{GB}$, as potential angiogenic agent, on the proliferation and differentiation of EPCs, as well as its putative mechanisms.

\section{Materials and Methods}

\section{Isolation and cultivation of EPCs}

Bone marrow was collected from the drill holes of the pedicle during internal spine fixation of patients with lumbar degenerative diseases (42 patients, age range 38-73 years, mean age 61 years, degenerative lumbar spondylolisthesis, disc herniation with lumbar spondylolisthesis, lumbar spinal stenosis with instability). Informed consent for bone marrow collection was obtained from the patients, and all procedures were performed in accordance with the guidance and approval of a research ethics committee in the First Affiliated Hospital of Sun Yat-sen University (NO. 2008-55).

The procedures for isolation, cultivation and identification of human EPCs cultures followed previously published methods (Asahara et al., 1997; Kalka et al., 2000). Briefly, mononuclear cells were collected from the bone marrow by density gradient centrifugation using Ficoll-Paque ${ }^{\mathrm{TM}}$ PREMIUM (1.077; GE Healthcare; www2.gehealthcare.com) according to the manufacturer's instructions. The isolated cells were cultivated in dishes coated with fibronectin and induced by EGM-2 MV SingleQuots (Cambrex, Charles City, IA, USA) at $37^{\circ} \mathrm{C}$ with 5\% $\mathrm{CO}_{2}$ in humidified air at density of $3-5 \times 10^{6} / \mathrm{cm}^{2}$. After $3 \mathrm{~d}$ in culture, non-adherent cells were removed by washing with phosphate-buffered saline (PBS), new medium was applied and the cultivation was maintained through $7 \mathrm{~d}$. Immuno-fluorescence staining and flow cytometry were used to indentify EPCs. Quantitative fluorescence-activated cell sorting (FACS) was performed on a FACS Vantage SE flow cytometer (Becton Dickinson, Franklin Lakes, NJ, USA). The Weibel-Palade body in cells was visualized by transmission electron microscopy (TEM). The ability of tube formation by EPCs was determined by in vitro angiogenesis assay.

\section{Chemicals}

GB (purity $\geq 99 \%$ by HPLC) was obtained from the National Institutes for Food and Drug Control, Beijing, China (http://www.nifdc.org.cn/directory/web/WS02/ CL0049/2191.html). GB was dissolved in dimethyl sulfoxide (DMSO; Sigma-Aldrich, St. Louis, MO, USA) at a concentration of $100 \mathrm{~g} / \mathrm{L}$.

\section{EPCs proliferation assay}

The effect of GB on EPCs proliferation was determined by 2-(2-methoxy-4-nitrophenyl)-3-(4-nitrophenyl)-5(2,4-disulfo-phenyl) -2H-tetrazolium, monosodium salt (WST-8) assay kit (CCK-8, Dojindo, Rockville, MD, USA) (Nojima et al., 2009). After cultivation for $7 \mathrm{~d}$, adherent cells were detached with $0.25 \%$ trypsin and cultured with non-FBS EBM-2 in 96-well culture plates at $8 \times 10^{3}$ cells per well for $24 \mathrm{~h}$. Then, the medium was replaced by fresh non-FBS EBM-2 with different concentrations of GB ( 0 , $1.25,5,20,80$ and $160 \mu \mathrm{g} / \mathrm{mL}$ ) for different periods. At 24 or $48 \mathrm{~h}, \mathrm{CCK}-8$ was used according to the manufacturer's instructions. WST- 8 was added into each well for $4 \mathrm{~h}$ before the measurement. The absorbance at $450 \mathrm{~nm}$ was measured using a microplate reader.

\section{EPCs migration assay}

EPC migration was evaluated by using a Transwell chamber assay as described before (Lee et al., 2009). In brief, human EPCs were maintained for $24 \mathrm{~h}$ in serum-free medium, pretreated with $0,5,20$ or $80 \mu \mathrm{g} / \mathrm{mL}$ GB for 48 h. Detached with trypsin, $1 \times 10^{5}$ EPCs were placed in the upper chamber of a 24 well Transwell (3422, Corning, Corning, NY, USA). $600 \mu$ L EGM-2 media containing 50 $\mathrm{ng} / \mathrm{mL}$ VEGF were placed into the lower compartment of the chamber. After $6 \mathrm{~h}$ incubation at $37^{\circ} \mathrm{C}$, EPCs on the top of the membrane was wiped off with a cotton swab. The Transwell membrane was rinsed with PBS $\left(37^{\circ} \mathrm{C}\right)$, and then incubated in 4\% paraformaldehyde at room temperature for $15 \mathrm{~min}$. For quantification, cells were stained with $0.1 \%$ crystal violet solution. Cells migrating into the lower chamber were counted manually in ten random microscopic fields.

\section{EPC adhesion assay}

The assay was done as described before (Lee et al., 2009). Human EPCs were starved, and treated with GB as above. Human EPCs were washed with PBS (containing 0.1\% BSA) and gently detached with $0.25 \%$ trypsin. Human EPCs at $1 \times 10^{4} /$ well in EGM-2, $2 \%$ FBS were replated onto fibronectin-coated 96 -well culture plate, and incubated for $30 \mathrm{~min}$ at $37^{\circ} \mathrm{C}$. After incubation, non-adherent cells were removed by washing three times with PBS. The adherent cells were fixed with $4 \%$ paraformaldehyde for $20 \mathrm{~min}$, washed with PBS, dyed with $100 \mu \mathrm{L} 0.1 \%$ crystal violet for $30 \mathrm{~min}$ at the room temperature. Adherent cells were counted by independent blinded investigators.

\section{In vitro angiogenesis assay}

In vitro angiogenesis assay was performed with an In Vitro Angiogenesis Assay Kit (Chemicon, CA, USA) according to the manufacturer's instructions (Urbich et al., 2005). Briefly, ECMatrix ${ }^{\mathrm{TM}}$ solution was thawed on ice overnight, mixed with $10 \times$ ECMatrix $^{\mathrm{TM}}$ diluents and placed in a 96-well tissue culture plate at $37^{\circ} \mathrm{C}$ for $1 \mathrm{~h}$ to allow the matrix solution to solidify. Human EPCs were starved, and treated with GB as described above. 10,000 cells/well were replated on the top of the solidified matrix 
solution. Tubule formation was inspected under an inverted light microscope at $200 \times$ magnification. Tubule formation was defined as a structure exhibiting a length four times its width. Five independent fields were assessed for each well, and the average number of tubules/200× field was determined.

\section{Effect of GB on the viability of $\mathrm{H}_{2} \mathrm{O}_{2}$-injured EPCs}

Human EPCs were starved, and treated with GB as described above. After that, the culture medium was replaced with EBM-2 containing $\mathrm{H}_{2} \mathrm{O}_{2}(150 \mu \mathrm{mol} / \mathrm{L})$ and the cells were cultured for another $6 \mathrm{~h}$. Cell viability was measured by CCK- 8 as described above. $2 \times 10^{6}$ cells/ well were plated in 6-well plates for the Annexin V FITC/ PI assay (Pharmingen, Becton Dickinson) to estimate apoptosis and necrosis. The percentage of apoptotic cells (annexin $\mathrm{V}$ positive and propidium iodide (PI) negative), necrotic cells (annexin V and PI positive) and cell debris (annexin V negative and PI positive), was analyzed.

\section{Enzyme-linked immunosorbent assay (ELISA)}

EPCs were cultivated and treated with GB as described in the viability/proliferation assay. After incubation with GB for $48 \mathrm{~h}$, the supernatants were harvested and used for ELISA assay, according to the manufacturer's instructions (Excell, Shanghai, China).

\section{Inhibition effect on proliferation of cell signaling pathway inhibitors}

EPCs were cultivated and treated with GB as described in the viability/proliferation assay. $1 \mu \mathrm{M}, 10 \mu \mathrm{M}$ or $100 \mu \mathrm{M}$ wortmannin (Sigma) was used alone or with $80 \mu \mathrm{g} / \mathrm{mL} \mathrm{GB}$ for 24 h. PD98059, LY294002 (both from Cell Signaling Technology, Danvers, MA, USA ) with the concentration of $1 \mu \mathrm{M}, 10 \mu \mathrm{M}$ or $100 \mu \mathrm{M}$ was added alone or with 80 $\mu \mathrm{g} / \mathrm{mL} \mathrm{GB}$ for $48 \mathrm{~h}$.

\section{Western blot analysis}

EPCs were collected and lysed with ice-cold lysing buffer (Novagen, Merck, Darmstadt, Germany). The protein concentration was determined by the Bradford assay. $20 \mu \mathrm{g}$ of total proteins were separated on a $10 \%$ SDS polyacrylamide gel. Bands on the gels were blotted onto polyvinylidene fluoride membranes (Millipore, Billerica, MA, USA). The proteins were detected with specific phospho-Akt, phospho-eNOS, phospho-p38 and Akt, eNOS, p38 antibodies (1:1000, all from Cell Signaling Technology). Protein bands were visualized with Chemiluminescence Reagent Plus (Thermo, Waltham, MA, USA) and exposured to X-ray film (Fujifilm, Tokyo, Japan). The bands were quantified with the Bandscan software 5.0.

\section{Real-time RT-PCR assay}

Total RNA of human EPCs was extracted by the TRIzol reagent (Invitrogen/Life Technologies, Carlsbad, CA, USA) as described by the manufacturer. The quantity and quality of the extracted RNA was confirmed by absorption measurement at 260 and $280 \mathrm{~nm}$ using the spectrophotometer (Beckman Coulter, Brea, CA, USA). cDNA synthesis was performed with $1 \mu \mathrm{g}$ of total RNA treated with DNase $\left(0.5 \mathrm{U} / \mu \mathrm{g}\right.$ RNA) with the PrimeScript ${ }^{\circledR}$
RT reagent Kit (Takara Bio, Shiga, Japan) according to the manufacturer's instructions. The expression of endothelial NOS (eNOS), kinase insert domain receptor (KDR), vascular endothelial growth factor (VEGF) and von Willebrand Factor (vWF) transcripts was detected with a real-time PCR kit (SYBR ${ }^{\circledR}$ Premix Ex Taq, Takara Bio) with specific primers (Takara Bio), using ABI Prism 7700 SDS apparatus (Applied Biosystems/Life Technologies). The mRNA fold changes were calculated on quadruple experiments by using the comparative critical threshold cycle (CT) $2^{\Delta \Delta C T}$ value.

\section{Statistical analysis}

All experiments were performed at least 3 times with cells from different donors, representative experiments are shown in the figures. The data shown are expressed as mean \pm SEM. Student's $t$-test was performed for statistical comparisons between two groups. The level of significance was set at $p<0.05$.

\section{Results}

\section{The growth process of EPCs}

When mononuclear cells isolated from human bone marrow were cultured in endothelial cell growth medium on fibronectin-coated dishes, both adherent and non-adherent cells demonstrated round morphology with different sizes as assessed by light microscopy during the first 3 days, suggesting the presence of various subpopulations within the human mononuclear cell fraction. Approximately $20 \%$ of the mononuclear cells transferred to culture plates grew as adherent cells during the first week of culture with a tendency to form clusters or colonies (Fig. 1A). When cultivated for 7 days, the adherent cells exhibited strong ability to take up Dil-acLDL and FITC-UEA-I, and the double positive rate was $(95.1 \pm 4.0) \%$ (Figure 1B), which were identified as differentiating EPCs. The Weibel-Palade body was observed in endochylema by TEM (Fig. 1D). During the second week of culture, the cells changed toward a spindle-shaped endothelium-like morphology. Then, attached cells formed a cobblestone-like structure at day 14 (Fig. 1A). 7 d-cultured EPCs (early EPCs) had more active angiogenic potential than $15 \mathrm{~d}$-cultured EPCs (late EPCs) (Fig. 1C). In the culture process, the expression pattern of surface markers changed toward a more mature endothelial cell phenotype during the cultivation period of 2 weeks, which showed a significant increase when $14 \mathrm{~d}$ cultures were compared to $7 \mathrm{~d}$ cultures with regard to the expression of vWF (from $5.4 \%$ to $38.9 \%$ ), KDR (from $66.7 \%$ to $81.8 \%$ ) and a marked decrease in expression of CD133 (from $18.5 \%$ to $3.8 \%$ ), and CD34 (from $45.4 \%$ to 36.1\%) (Fig. 1E).

\section{GB promotes proliferation capacity of EPCs}

The effect of GB on the proliferative activity of EPCs was investigated by CCK-8. As shown in Fig. 2A, incubation of human EPCs with GB for $48 \mathrm{~h}$ dose-dependently increased the number of EPCs, which was maximal at $80 \mu \mathrm{g} / \mathrm{mL} \mathrm{GB}$, but at a dose of $160 \mu \mathrm{g} / \mathrm{mL}$, no obvious increase compared to control was observed. An increase in EPC proliferative 
A

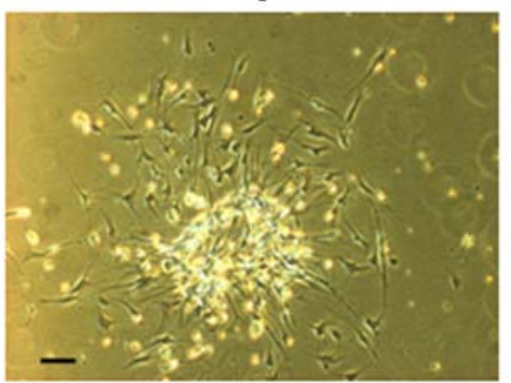

B FITC-UEA-I

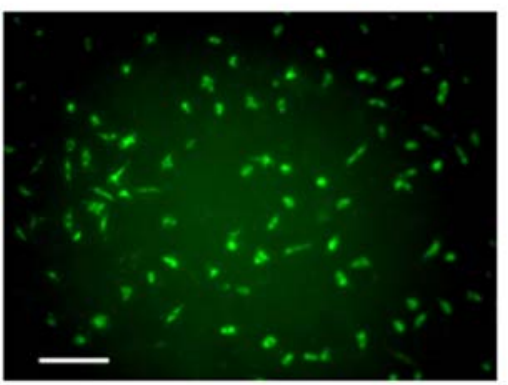

C 7 days

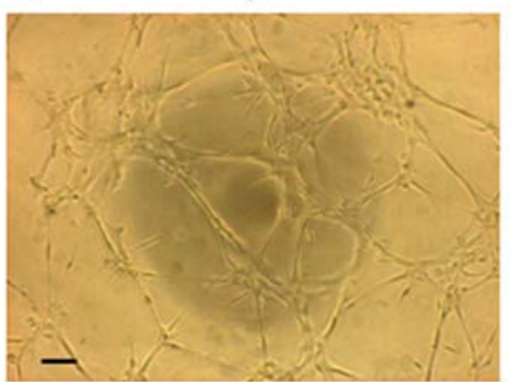

D

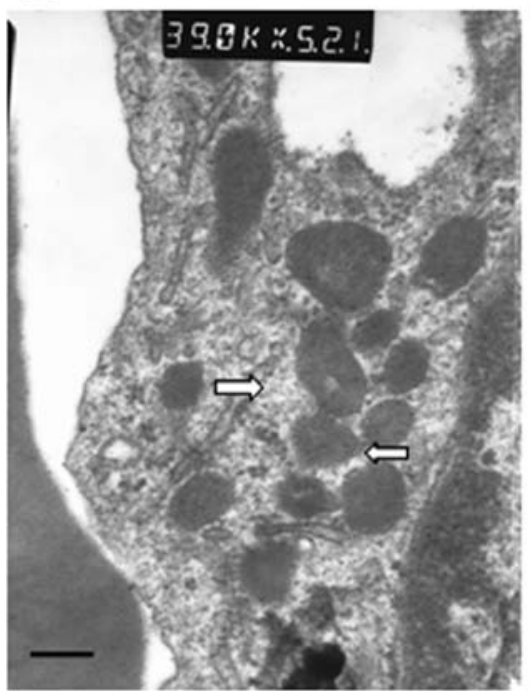

11 days

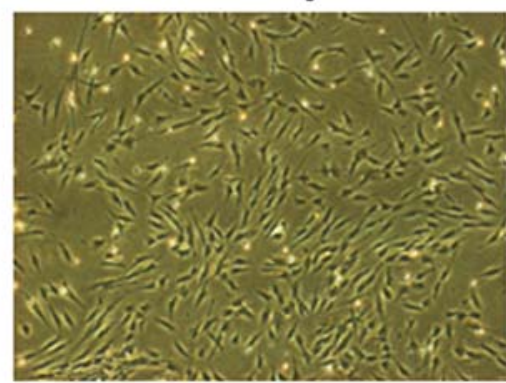

Dil-acLDL

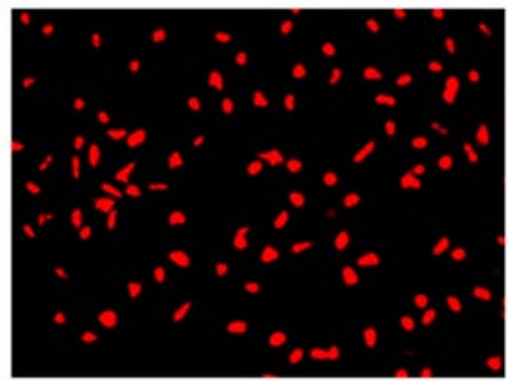

15 days

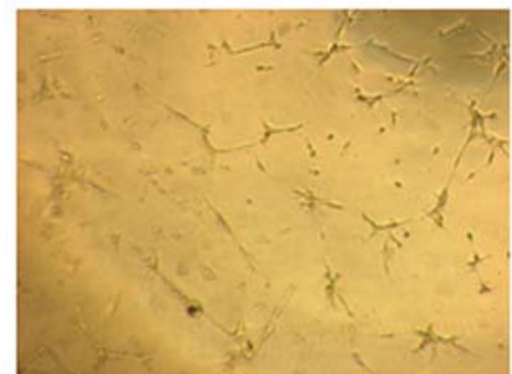

E
14 days

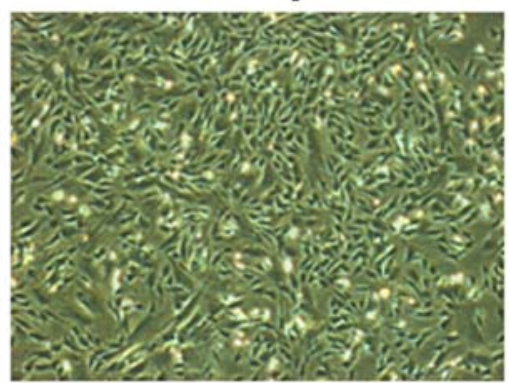

FITC-UEA-I+Dil-acLDL

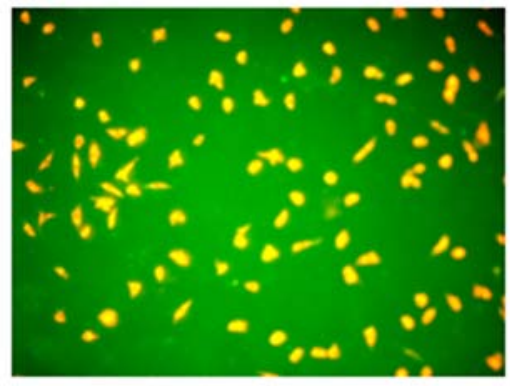

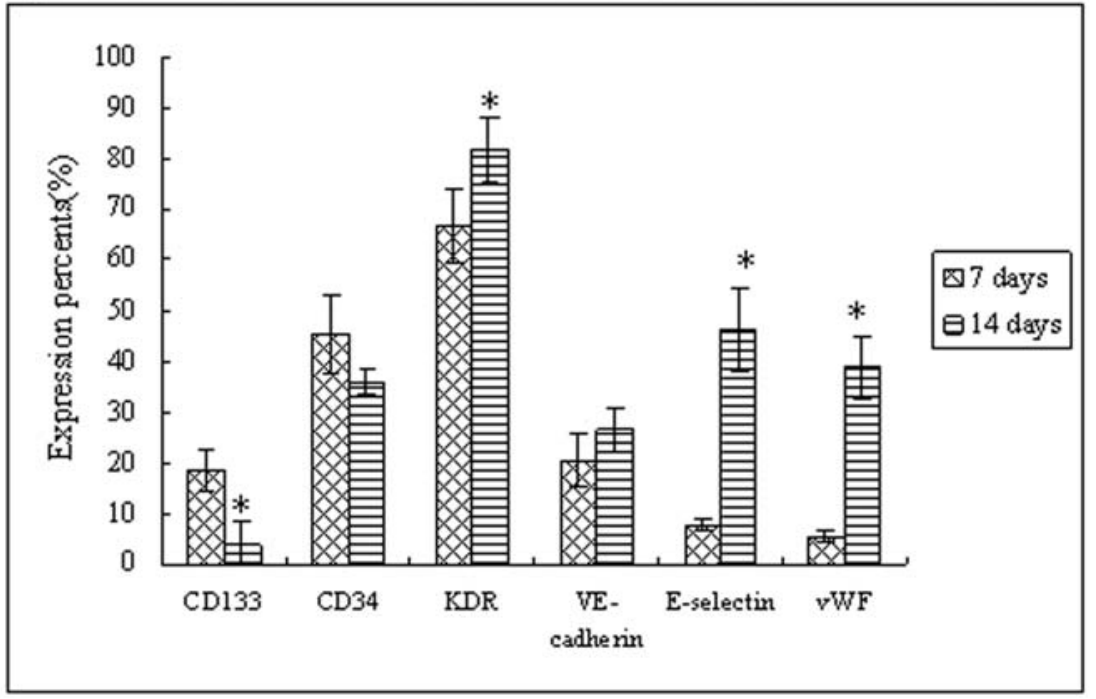

Fig. 1. (A) The morphology of EPCs in different growth periods. 7 days-cultured EPCs formed apparent colonies. 11 d-cultured EPCs were elongated and had a spindle shape. 14 d-cultured EPCs grown to confluence show a cobblestone-like monolayer. (B) EPC characterization by immunofluorescence. Binding to FITC-UEA-I, endocytosis of Dil-acLDL, and double positive cells appearing yellow in the overlay were identified as differentiating EPCs. (C) Differences between the two culture periods of EPCs of the ability to form tubes on the ECM in vitro. (D) A WeibelPalade body (arrow) was observed in the endochylema by TEM. (E) The expression pattern of cell surface markers. The percentage of expression of CD133, CD34, KDR, VE-Cadherin, E-selectin and vWF was determined by flow cytometry at $7 \mathrm{~d}$ and $14 \mathrm{~d}$ culture. ( $\left.{ }^{*}\right) p<0.05$ versus the results for $7 \mathrm{~d}$. Bar in $\mathbf{A}, \mathbf{B}, \mathbf{C}=100 \mu \mathrm{m}$, in $\mathbf{D}=200 \mathrm{~nm}$. 

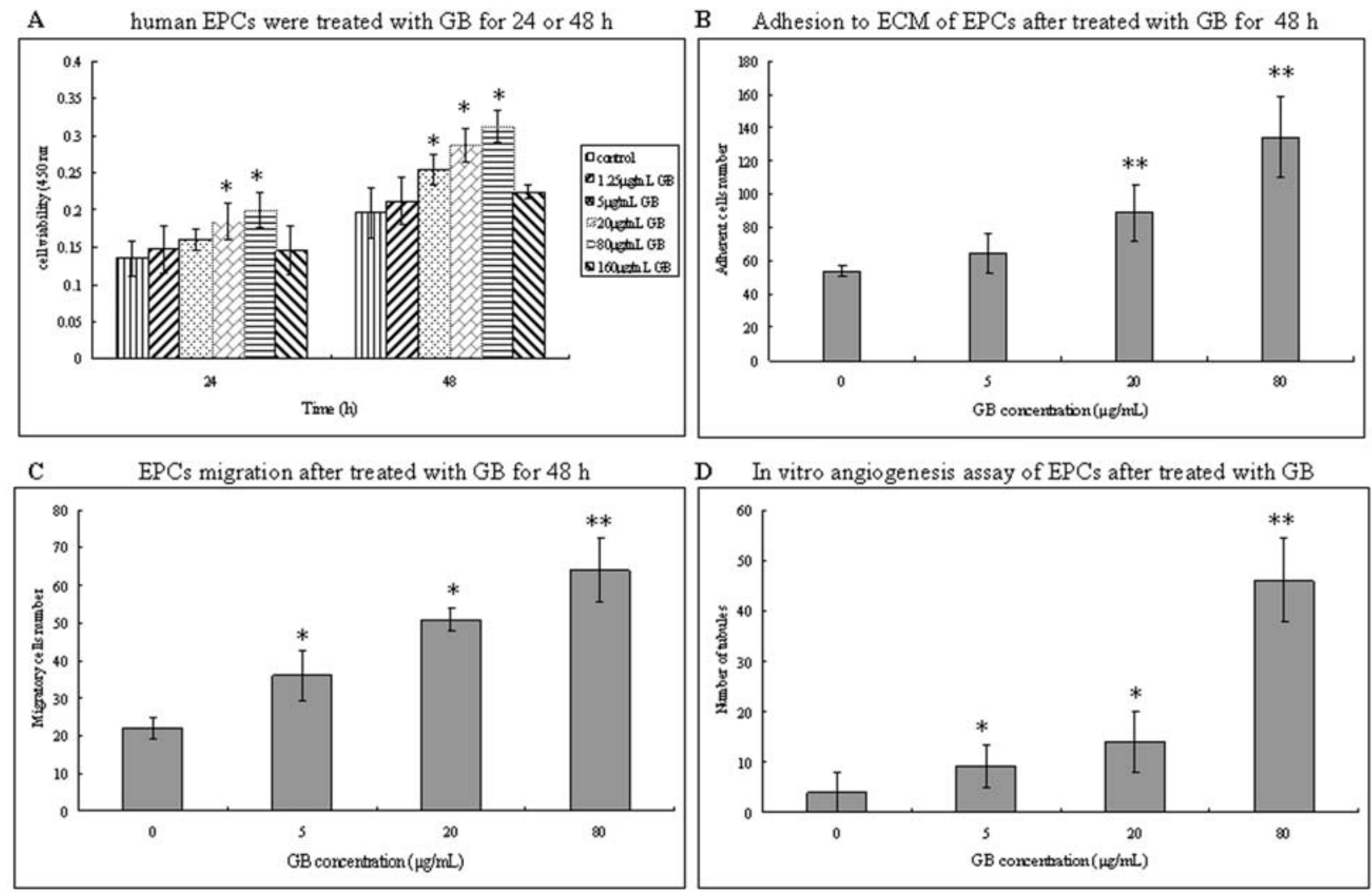

D In vitro angiogenesis assay of EPCs after treated with $\mathrm{GB}$
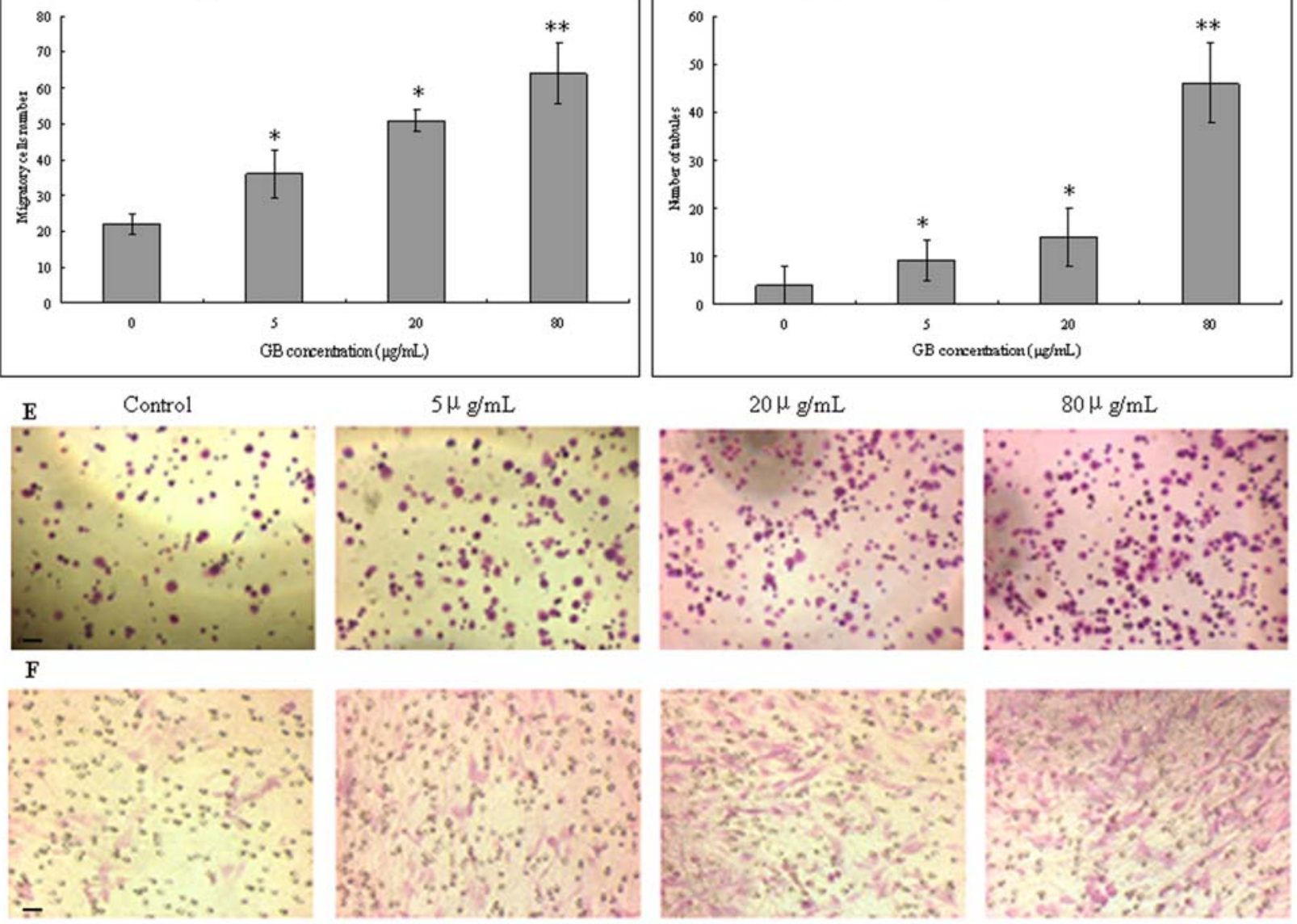

G
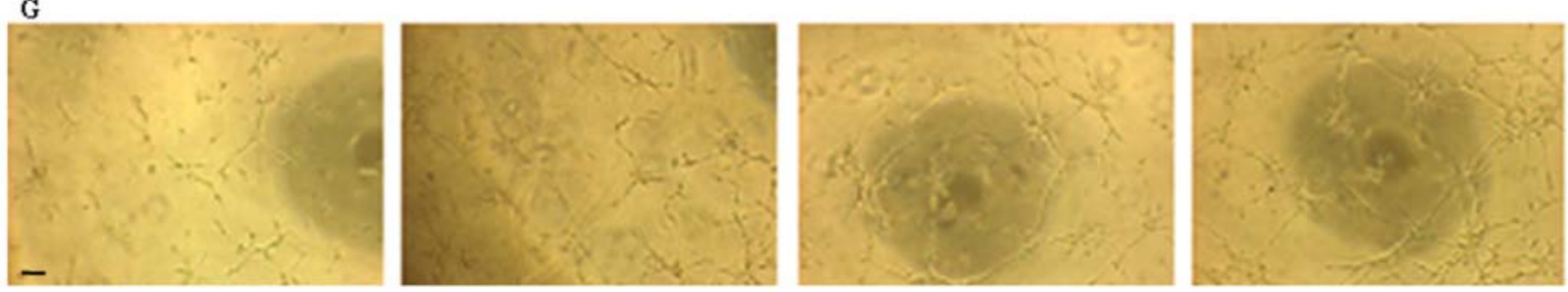

Fig. 2. (A) Human EPCs were starved in serum-free medium for $24 \mathrm{~h}$, then treated with GB for another $24 \mathrm{~h}$ and $48 \mathrm{~h} .1 .25$ and $160 \mu \mathrm{g} / \mathrm{mL}$ GB showed no effect on the proliferation of EPCs in 24 and $48 \mathrm{~h}$. EPC proliferation was enhanced by 20 and $80 \mu \mathrm{g} / \mathrm{mL}$ GB for $24 \mathrm{~h}$, and by 5,20 and $80 \mu \mathrm{g} / \mathrm{mL} \mathrm{GB}$ for $48 \mathrm{~h}, N=8$. (B) After human EPCs were incubated with GB for $48 \mathrm{~h}, \mathrm{EPC}$ adhesion to ECM was increased when the cells were incubated with 20 and $80 \mu \mathrm{g} / \mathrm{mL} \mathrm{GB}$, but not with $5 \mu \mathrm{g} / \mathrm{mL} \mathrm{GB}, N=5$. (C) Pretreatment with 5,20 and $80 \mu \mathrm{g} / \mathrm{mL} \mathrm{GB}$ for $48 \mathrm{~h}$ increased human EPC migration to the lower surface of the membrane of Transwell chambers, $N=5$. (D) GB preincubation for $48 \mathrm{~h}$ enhanced capillary-like tube formation of EPCs in a dose-dependent manner from 5 to $80 \mu \mathrm{g} / \mathrm{mL}, N=5$. Representative pictures of adhesion, migration, and in vitro angiogenesis of 0 to $80 \mu \mathrm{g} / \mathrm{mL} \mathrm{GB}$ pretreated human EPCs are shown in $(\mathbf{E}),(\mathbf{F})$, and $(\mathbf{G})$ respectively. $(*) p<0.05,(* *) p<0.01$ versus the control group. Bar $=100 \mu \mathrm{m}$. 

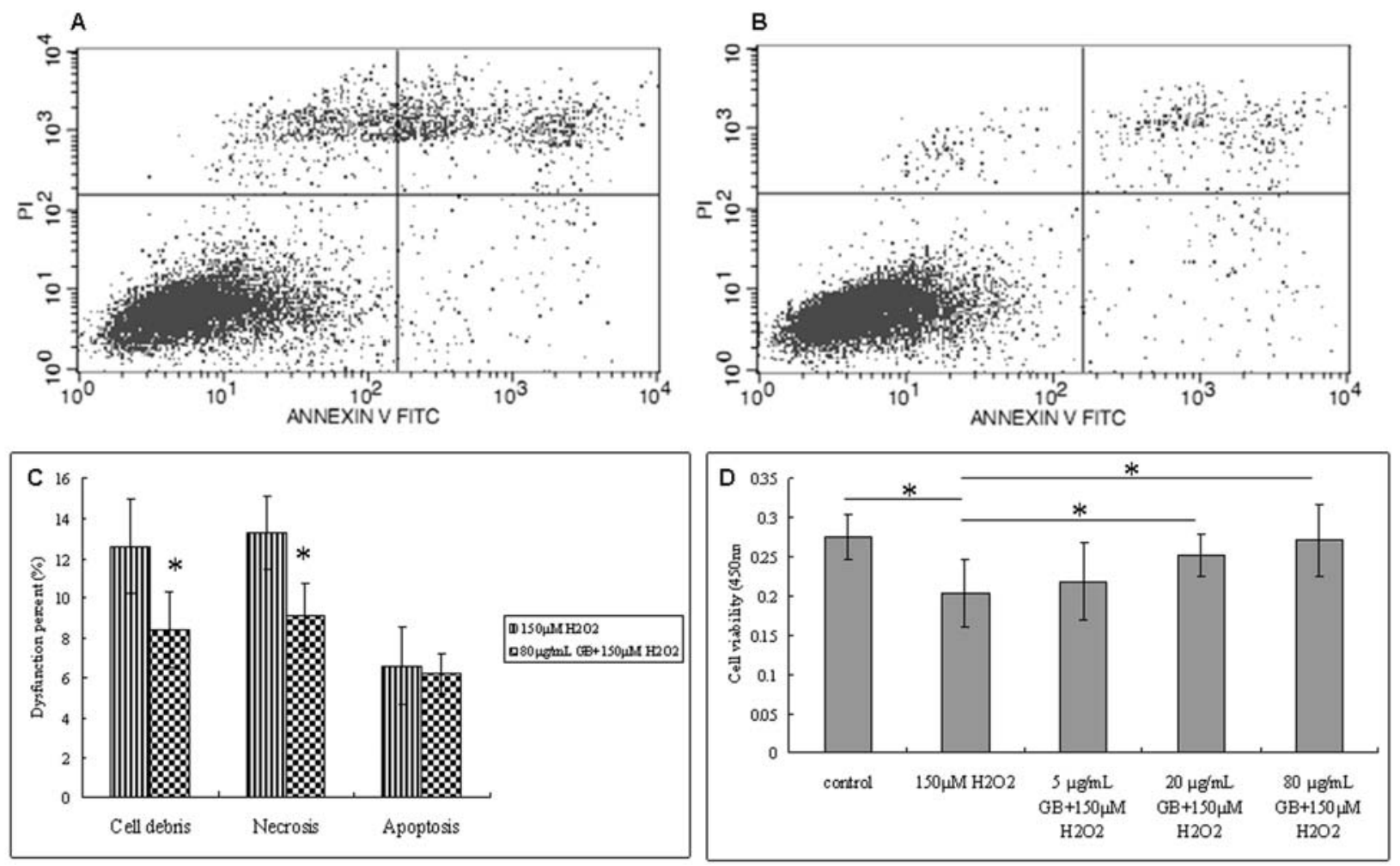

Fig. 3. Effects of GB on $\mathrm{H}_{2} \mathrm{O}_{2}$ induced cell dysfunction. Cells were pre-incubated with or without various concentrations of $\mathrm{GB}$ for $48 \mathrm{~h}$, and then treated with $150 \mu \mathrm{M} \mathrm{H}_{2} \mathrm{O}_{2}$ for $6 \mathrm{~h}$. Examples of dot plots, as determined by flow cytometry, following annexin V and PI double staining. The horizontal axis represents annexin V intensity, and the vertical axis shows PI staining. The lines divide each plot into four quadrants: lower left quadrant (living cells), lower right quadrant (apoptotic cells), upper left quadrant (necrotic cells), and upper right quadrant (debris). Representative results showed cell apoptosis, necrosis, and debris when cells were treated with $80 \mu \mathrm{g} / \mathrm{mL} \mathrm{GB}$ (B) or without it (A), followed by $150 \mu \mathrm{M} \mathrm{H}_{2} \mathrm{O}_{2}$ for $6 \mathrm{~h}$. (C) Inhibitory effect of $\mathrm{GB}$ on $\mathrm{H}_{2} \mathrm{O}_{2}$ induced cell apoptosis and necrosis was expressed as a percentage. The apoptosis, necrosis, and debris rates were $6.6 \%, 13.3 \%$ and $12.6 \%$ respectively without GB. After pretreatment with GB, the apoptosis, necrosis, and debris rate decreased to $6.2 \%, 9.1 \%$ and $8.4 \%$, respectively. $N=3$. (D) Incubation with $150 \mu \mathrm{M} \mathrm{H}_{2} \mathrm{O}_{2}$ for $6 \mathrm{~h}$ significantly reduced the cell viability, $\mathrm{GB}$ alleviated the damage to EPCs by $150 \mu \mathrm{M} \mathrm{H}_{2} \mathrm{O}_{2}$ in a dose-dependent manner from 5 to $80 \mu \mathrm{g} / \mathrm{mL}$. $N=6$. ( $\left.{ }^{*}\right) p<0.05$ versus the control group.

activity at $80 \mu \mathrm{g} / \mathrm{mL}$ GB became apparent at $24 \mathrm{~h}$ and reached a maximum at $48 \mathrm{~h}$.

\section{Adhesion to ECM was increased by GB}

To investigate the possibility that GB alters the adhesiveness of cultured human EPCs, EPCs were incubated with GB for $48 \mathrm{~h}$. After replating on fibronectin-coated dishes, EPCs pre-exposed to GB exhibited a significant increase in the number of adhesive cells at $30 \mathrm{~min}$. The number of adhesive cells began to increase after treated with $5 \mu \mathrm{g} /$ $\mathrm{mL} \mathrm{GB}$ and in a dose-dependent manner $(p<0.01$; Figs. 2B, 2E).

\section{GB enhances the migratory activity of EPCs}

It is known that promotion of cell mobility and maintenance of cell survival signaling are essential for capillary tube formation. Thus, we further investigated whether GB can affect the migrative activity of EPCs. The cellular response of GB-treated EPCs to VEGF-induced migration was examined using the Transwell assay. GB ( $22 \pm 2.6$ vs. 64 \pm 6.5 cells/field for control and $80 \mu \mathrm{g} / \mathrm{mL} \mathrm{GB}$, respectively; $p<0.01)$ also concentration-dependently enhanced EPCs migratory activity, which became apparent at $5 \mu \mathrm{g} / \mathrm{mL}(p<$ 0.05 ) and reached a maximum at $80 \mu \mathrm{g} / \mathrm{mL}$ (Figs. 2C, 2F).

\section{GB augments the capillary-like tube formation}

In vitro angiogenesis assay was used to investigate the ability of EPCs to participate in vascularization, which is the most important activity of EPCs. The response of the EPCs to GB is shown in Fig. 2D, and Fig. 2G. Tubule number increased in a dose-dependent fashion in response to $\mathrm{GB}$ at $48 \mathrm{~h}$ of incubation, with peak tubule numbers observed in the presence of $80 \mu \mathrm{g} / \mathrm{mL}$ GB. Moreover, tubules in GB-treated wells were qualitatively different and more complex than those in control wells.

\section{Protective effect of GB on the $\mathrm{H}_{2} \mathrm{O}_{2}$-injured EPCs}

EPCs were exposed to increasing concentrations of $\mathrm{H}_{2} \mathrm{O}_{2}$ from 0 to $1,000 \mu \mathrm{mol} / \mathrm{L}$ for $6 \mathrm{~h}$ (data from the pilot study not shown). Our studies showed that $150 \mu \mathrm{mol} / \mathrm{L} \mathrm{H}_{2} \mathrm{O}_{2}$ is the proper concentration. The treatment of cells with $\mathrm{GB}^{2}$ in the presence of $150 \mu \mathrm{mol} / \mathrm{L} \mathrm{H}_{2} \mathrm{O}_{2}$ protected the cells against the cytotoxicity effect of $\mathrm{H}_{2} \mathrm{O}_{2}$ (Fig. 3D). Following $\mathrm{H}_{2} \mathrm{O}_{2}$ treatment, EPCs apoptosis and necrosis were examined. 

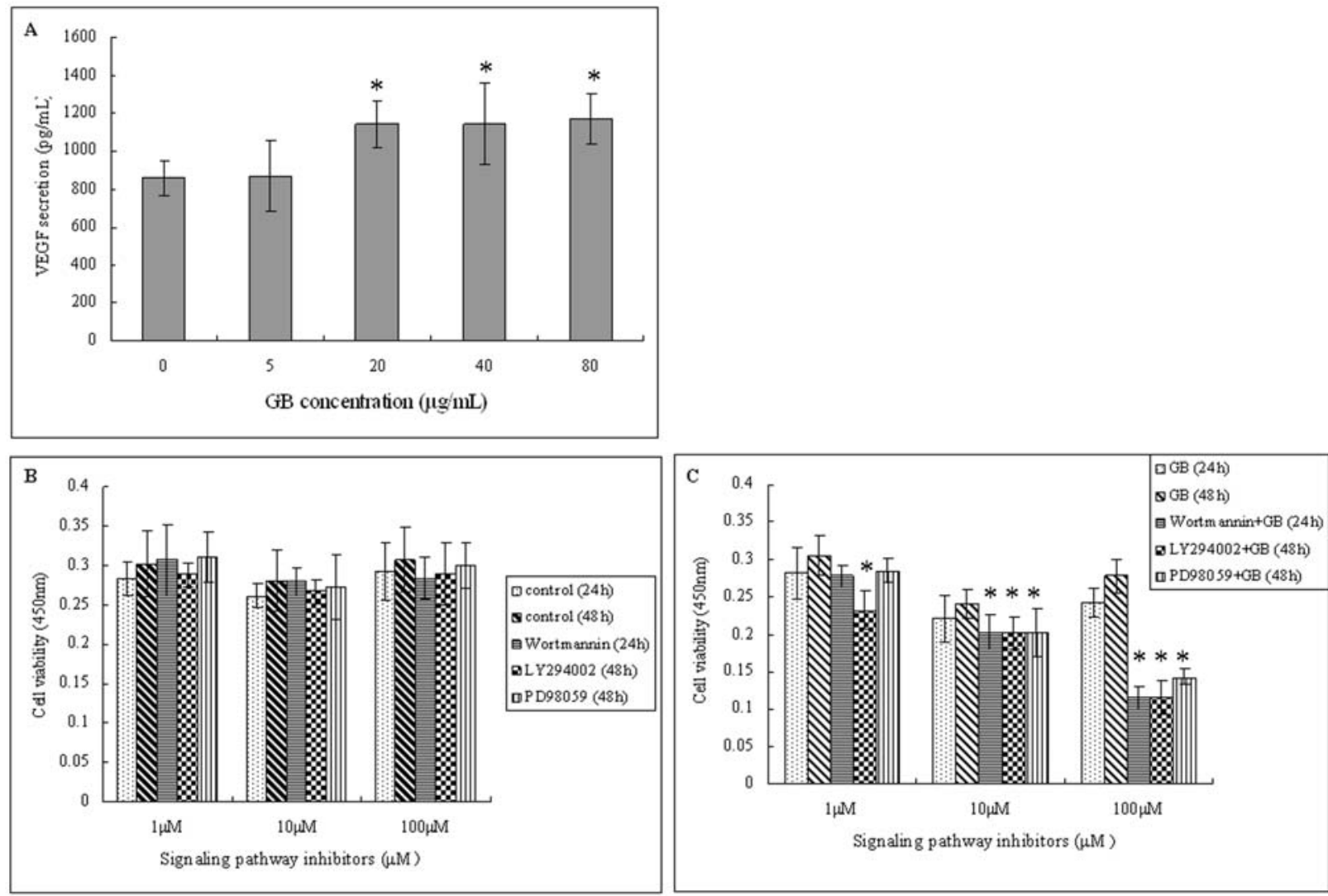

Fig. 4. (A) The VEGF secretion of EPCs treated with or without GB for $48 \mathrm{~h}$. Cell supernatants were then collected and used for ELISA analysis. Compared with the control group, VEGF secretion was increased by the presence of GB at 20, 40 and $80 \mu \mathrm{g} / \mathrm{mL}$. (B) To characterize the relative roles of Akt and MAPK/ERK pathway on GB-induced proliferation, PI3K and MEK1 inhibitors (wortmannin and LY294002 for PI3K, PD98059 for MEK1) were used. At concentrations of 1, 10 and $100 \mu \mathrm{M}$, the growth of EPCs was not affected by wortmannin for $24 \mathrm{~h}$, by LY294002 or PD98059 for 48 h, (C) Wortmannin (10 and $100 \mu \mathrm{M})$ in 24 h, LY294002 (1, 10 and $100 \mu \mathrm{M})$ or PD98059 (10 and $100 \mu \mathrm{M}$ ) for $48 \mathrm{~h}$ significantly attenuated the cell proliferation induced by $80 \mu \mathrm{g} / \mathrm{mL} \mathrm{GB}$. ( $\left.{ }^{*}\right) p<0.05$ versus the control group.

Flow cytometry analysis indicated the protective effect of GB against oxidative damage induced apoptosis by $\mathrm{H}_{2} \mathrm{O}_{2}$ (Figs. 3A, 3B). The dysfunctional cell rates decreased from $32.5 \%$ (apoptosis rate $6.6 \%$, necrosis rate $13.3 \%$, and debris rate $12.6 \%$, without pretreatment with GB) to $23.7 \%$ (apoptosis rate $6.2 \%$, necrosis rate $9.1 \%$, and debris rate $8.4 \%$, pretreated with GB) (Fig. 3C).

\section{Effects of GB on VEGF secretion}

Because of the important role of VEGF in the regulation of angiogenesis and cell function, we evaluated the secretion level of VEGF in EPCs. Over a period of incubation of 48 $\mathrm{h}$ with GB, the concentration of VEGF in the supernatant became significantly greater for EPCs treated with GB at 20,40 or $80 \mu \mathrm{g} / \mathrm{mL}$ than for untreated (control) EPCs $(859.6 \pm 69.2 \mathrm{pg} / \mathrm{mL} v s .1174 .5 \pm 110.6 \mathrm{pg} / \mathrm{mL}$, for control and $80 \mu \mathrm{g} / \mathrm{mL} \mathrm{GB}$, respectively; $p<0.05$; Fig. 4A).

\section{The activation of AKT and ERK pathways mediates the effects of GB on EPCs}

We examined the signaling molecules that were responsible for cell growth upon GB stimulation. To characterize the relative roles of PI3K/Akt and MAPK/ERK on GB- induced proliferation, three different selective inhibitors (wortmannin and LY294002 for PI3K, PD98059 for MEK1) were used. At the concentrations of $1 \mu \mathrm{M}, 10 \mu \mathrm{M}$ and $100 \mu \mathrm{M}$, all three inhibitors did not affect the growth of control EPCs (Fig. 4B). But the cell number when treated with GB and inhibitors were significantly decreased compared to treatment with GB alone $(p<0.05)$ (Fig. 4C). These results suggested a link between GB-induced EPCs proliferation and both Akt and ERK-activated signaling pathways.

To further investigate the molecular mechanisms underlying the effects of GB on EPCs, the phosphorylation status of Akt, eNOS and p38, which are implicated in EPCs proliferation and function, was examined by Western blot analysis. Under the conditions used in the present experiments, GB stimulated Akt expression, an effect that was more evident at the higher concentrations, while the total Akt levels remained unchanged. Since VEGF requires Akt to augment EPCs numbers, this suggested an essential role for Akt in regulating EPCs differentiation (Figs. 5A, 5B). In addition, eNOS phosphorylation in EPCs was also significantly induced after GB treatment. To further define the roles of MAPK in the GB-induced effects on EPCs, we 
A
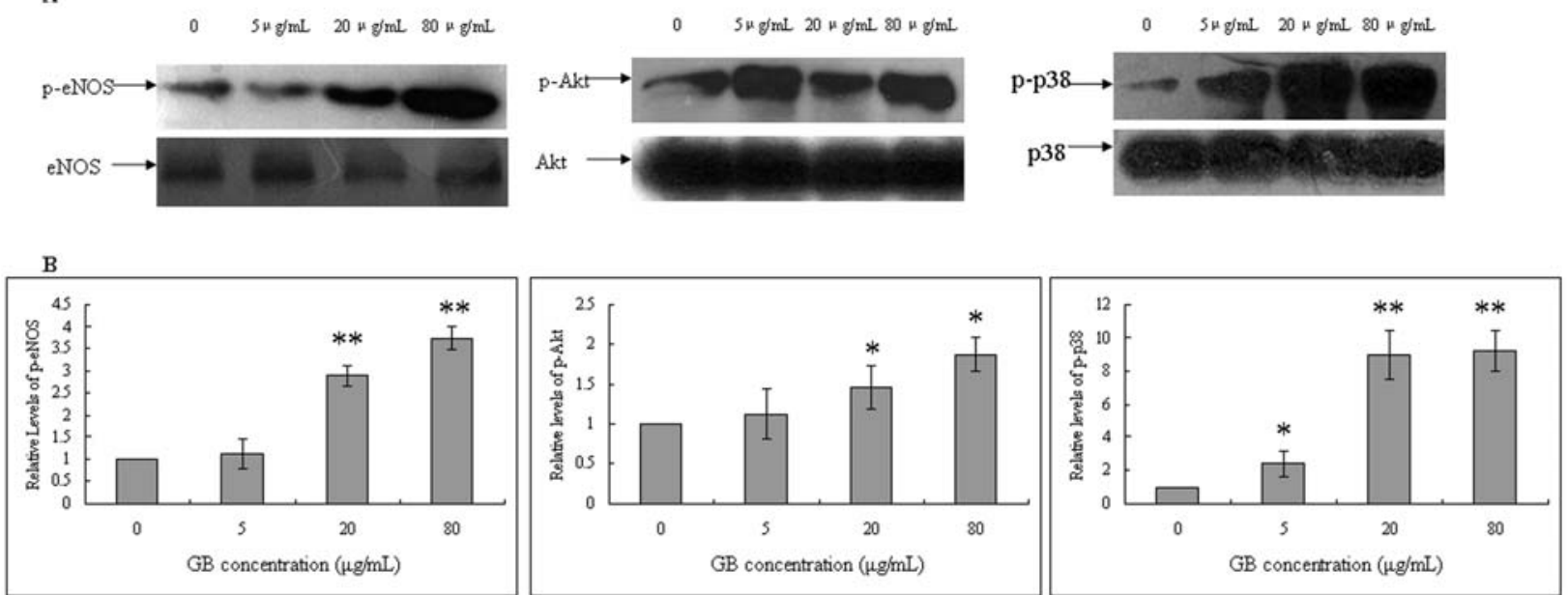

c
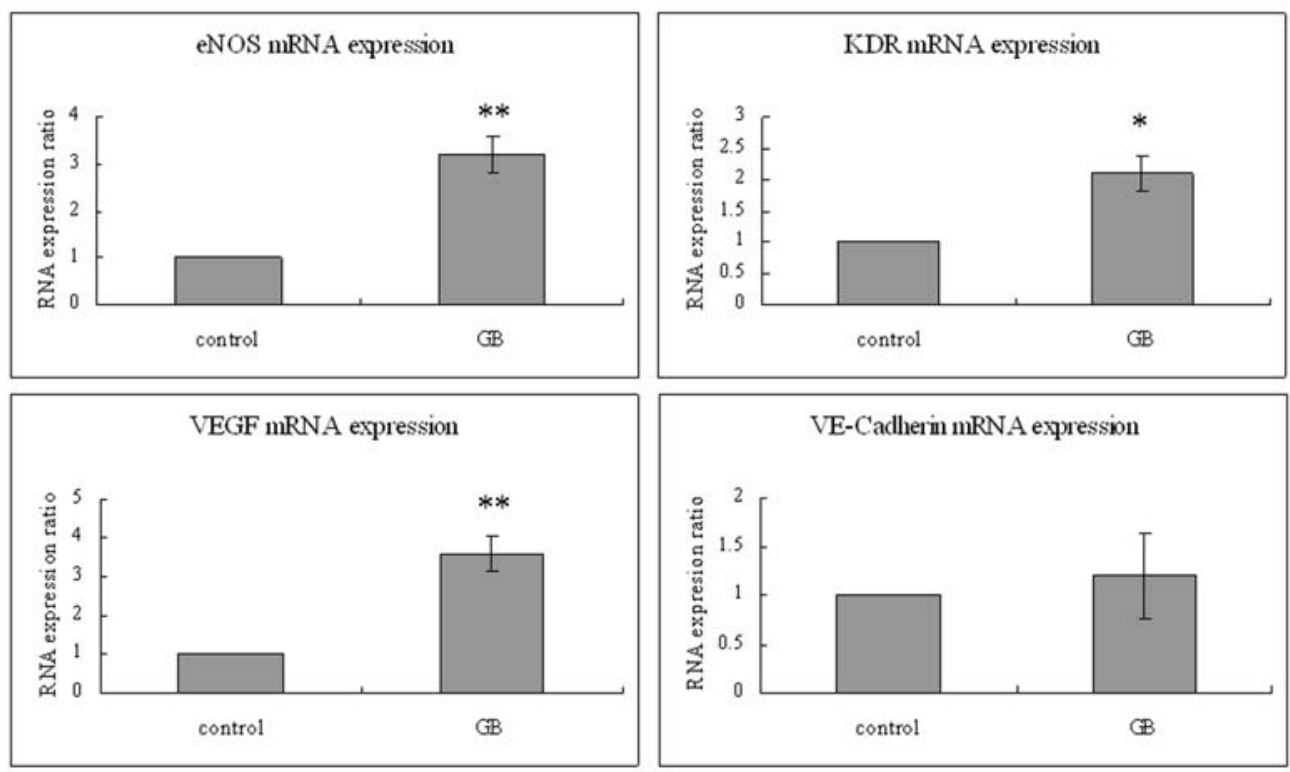

Fig. 5. GB induces the phosphorylation of Akt, eNOS and p38. (A) EPCs were treated with the indicated concentrations of GB for $48 \mathrm{~h}$. The phosphorylation states of the indicated kinases were then examined by Western blotting. (B) Quantification of the levels of phospho-Akt, phospho-eNOS and phospho-p38 by densitometry analysis. (C) GB induces endothelial gene expression. EPCs were incubated without (control) or with $80 \mu \mathrm{g} / \mathrm{mL}$ GB for $48 \mathrm{~h}$. Total RNA was extracted and the expression of indicated genes was determined by RT-PCR. $(*) p<0.05,(* *) p<0.01$ versus the control group.

analyzed the expression of phosphorylated p38 following GB treatment. As demonstrated in Fig. 5A, GB activated the phosphorylated p38 levels significantly, suggesting that p38 is involved in the stimulatory effect of GB on EPCs.

\section{GB upregulates the expression of endothelial genes}

VEGF, eNOS, KDR and VE-adherin are well known as endothelial genes that are involved in the functions of EPCs. To examine whether GB treatment affected the expression of these genes in EPCs, we performed quantitative real-time (RT)-PCR. As shown in Fig. 5C, the expression level of eNOS increased in GB-treated human EPCs over threefold when compared with a vehicletreated control $(p<0.01)$. The expression of KDR was also enhanced by GB treatment, although to a lesser extent ( $p$
$<0.05$; Fig. 5C). Additional experiment was performed to determine the expression level of VEGF, which is a gene implicated in the proliferation and differentiation of EPCs in an autocrine manner. There was a significant increase in the expression of VEGF ( $p<0.01$; Fig. $5 \mathrm{C}$ ). But GB treatment did not seem to significantly affect the expression of VE-cadherin in EPCs.

\section{Discussion}

For the first time, the present study demonstrated that $\mathrm{GB}$, at a near medical applied dose, enhanced the ex vivo expansion of EPCs with increased functional activities. GB increased the number of EPCs in a dose and time dependent 
manner which became apparent at $20 \mu \mathrm{g} / \mathrm{mL}$ at $24 \mathrm{~h}$, peaking at $80 \mu \mathrm{g} / \mathrm{mL}$ at $48 \mathrm{~h}$. Homing and incorporation of EPCs into the sites of revascularization probably are determined not only by the number of circulating EPCs but also by EPC maturation and/or differentiation. In this regard, our present data showed that GB also promoted EPCs migration and adhesion in an approximate dose and time dependent manner. Moreover, GB effectively induced EPCs tubule formation in vitro accompanied by upregulation of VEGF. VEGF is known to be the master stimulus of angiogenesis through binding to two receptor tyrosine kinases, Flt-1 and KDR, which belong to the PDGF receptor superfamily (Ferrara, 1999). Based on the aforementioned analysis, in turn, GB could regulate EPCs mobilization and differentiation, and contribute to the proangiogenic effects of those cells.

Dimmeler et al. have shown that VEGF, as well as statins, induced EPC differentiation via the PI3K/Akt pathway, as demonstrated by the inhibitory effect of pharmacological PI3K blockers or the over expression of a dominant negative Akt construct. Statins increased the numbers of EPCs via a PI3K dependent pathway, which is putatively related to the release of nitric oxide, causing a reduction in the rate of apoptosis of EPCs (Dimmeler et al., 2001; Imanishi et al., 2008). Activation of Akt promoted endothelial cell survival by inhibiting apoptosis (Dimmeler et al., 1998), stimulated endothelial NO synthesis (Fulton et al., 1999), and mediated VEGFinduced endothelial cell migration (Kawasaki et al., 2008). Recent studies have also provided increasing evidence that MAPK signaling is critical during the endothelial differentiation of vascular progenitor cells (Xu et al., 2008). In order to detect the role of PI3K/Akt and MAPK in the GB-induced angiogenic response of EPCs, we performed additional experiments in which MAPK and Akt activation was blocked by the pharmacological agents wortmannin, LY294002, and PD98059 respectively. Our data showed that at concentrations that did not affect the growth of control EPCs, all three inhibitors significantly attenuated the cell proliferation induced by GB, suggesting that activation of the Raf/MEK and PI3K/Akt pathways is crucial for promoting cell growth and function. To explore whether these kinases play a role in the GB induced angiogenic response of EPCs, and to elucidate the molecular mechanisms allowing commitment of EPCs to enhanced cell functional activity in the presence of GB, the phosphorylated status of Akt, eNOS and p38 following GB treatment was assessed. Our data indicated that GB induced the transient activation of Akt, eNOS and p38. Collectively, these data may support that GB promotes the proliferation and differentiation of these cells and enhances their function via the activation of Akt and MAPK/p38.

Although the proportional contribution of angiogenesis and vasculogenesis to neovascularization of adult tissue remains to be determined, it has been shown, either by mobilization of EPCs or by injection of in vitrocultured hematopoietic stem cells, that EPCs improved neovascularization of the hind limb and cardiac function (Kalka et al., 2000; Murohara, 2003). EPCs in peripheral blood and bone marrow have been implicated in revascularization, vascular repair, and smoothly blood supply (Asahara et al., 1997; Dimmeler et al., 2001; Kalka et al., 2000; Walter et al., 2002), represented a very interesting alternative cell source for enhancing the vasculogenesis in regenerative medicine (Avci-Adali et al., 2011; Finkenzeller et al., 2007). Therefore, further understanding of the mechanisms that regulate EPCs mobilization and differentiation may provide new insights for the use of GB.

Many antioxidant and anti-inflammatory mechanisms are involved in the protection of injured vascular endothelial cells by the use of pharmaceutical agents. In the present study, exposure of $\mathrm{H}_{2} \mathrm{O}_{2}$ to EPCs had induced oxidative damage and loss of cell viability. This finding is in accordance with previous results that reported the oxidant-mediated cellular injury by $\mathrm{H}_{2} \mathrm{O}_{2}$ on human umbilical vein endothelial cells and other cell types like human fibroblast cells and endometrial cells (Spencer et al., 2001; Estany et al., 2007; Cianchetti et al., 2008). As far as the results of the current study are concerned, the harmful effect of $\mathrm{H}_{2} \mathrm{O}_{2}$ and the protective effect of GB are mainly related to their oxidant and antioxidant activity. Since the WST-8 assay is a measure of total cell viability and the results should reflect changes in both cell proliferation as well as cellular damage, we characterized the specific effects of GB on levels of apoptosis and necrosis. The data showed that GB preserved the cell viability as well as protected against $\mathrm{H}_{2} \mathrm{O}_{2}$-induced cell damage in EPCs.

In summary, the results of the present study demonstrate that GB promotes EPCs proliferation, migration, adhesion and induction of angiogenesis in vitro through upregulation of VEGF. There are several possible scenarios by which GB could increase the number and functional activities of BM-EPCs. One explanation might be the decrease of apoptosis of premature progenitor cells. Secondly, GB may interfere with the signal pathways regulating EPCs differentiation. These findings raise the intriguing possibility that GB may play an important role in the protection and revascularization of blood vessels. Further studies are needed to determine whether GB could increase EPC-mediated new vessel formation in vivo, which is beneficial to inducing neoangiogenesis for regenerative medicine.

\section{Acknowledgements}

This study was supported by the Key Program of National Natural Science Foundation of ChinaGuangdong Joint Funding (Grant No. u0732001), Key International S\&T Cooperation Project of Ministry of Science and Technology of the People's Republic of China (Grant No. 2005DFA30570), the International S\&T Cooperation Network Project of Danish Council for Strategic Research for Individualized Musculoskeletal Regeneration and Reconstruction Network (Grant No. 2101-07-0120), Project of Chinese-German Junior Research Group on Biotechnology (Grant No. 2009004) and Guangdong Natural Science Foundation (Grant No. 8151008901000167). We thank Dr. Wenjian Wang, Dr. Wen Li and Longjuan Zhang from the Surgical Laboratory at the First Affiliated Hospital of Sun Yat-sen University for their excellent technical help. 


\section{References}

Ahlemeyer B, Möwes A, Krieglstein J (1999) Inhibition of serum deprivation- and staurosporine-induced neuronal apoptosis by Ginkgo biloba extract and some of its constituents. Eur J Pharmacol 367: 423-430.

Akiba S, Kawauchi T, Oka T, Hashizume T, Sato $\mathrm{T}$ (1998) Inhibitory effect of the leaf extract of Ginkgo biloba L. on oxidative stress-induced platelet aggregation. Biochem Mol Biol Int 46: 1243-1248.

Asahara T, Murohara T, Sullivan A, Silver M, van der Zee R, Li T, Witzenbichler B, Schatteman G, Isner JM (1997) Isolation of putative endothelial progenitor cells for angiogenesis. Science 275: 964-967.

Avci-Adali M, Perle N, Ziemer G, Wendel HP (2011) Current concepts and new developments for autologous in vivo endothelialisation of biomaterials for intravascular applications. Eur Cell Mater 21: 157-176.

Bourgain RH, Andries R, Braquet P (1987) Effect of ginkgolide PAF-acether antagonists on arterial thrombosis. Adv Prostaglandin Thromboxane Leukot Res. 17B: 815817.

Carmeliet P (2000) Mechanisms of angiogenesis and arteriogenesis. Nat Med 6: 389-395.

Chang J, Li Y, Huang Y, Lam KS, Hoo RL, Wong WT, Cheng KK, Wang Y, Vanhoutte PM, Xu A (2010) Adiponectin prevents diabetic premature senescence of endothelial progenitor cells and promotes endothelial repair by suppressing the p38 MAP kinase/p16INK4A signaling pathway. Diabetes 11: 2949-2959.

Cianchetti S, Fiorentino AD, Colognato R, Di Stefano R, Franzoni F, Pedrinelli R (2008) Anti-inflammatory and anti-oxidant properties of telmisartan in cultured human umbilical vein endothelial cells. Atherosclerosis 198: 2228.

Coyle AJ, Page CP, Atkinson L, Sjoerdsma K, Touvay C, Metzger WJ (1989) Modification of allergen-induced airway obstruction and airway hyperresponsiveness in an allergic rabbit model by the selective platelet-activating factor antagonist, BN 52021. J Allergy Clin Immunol 84: 960-967.

Dimmeler S, Assmus B, Hermann C, Haendeler J, Zeiher AM (1998) Fluid shear stress stimulates phosphorylation of Akt in human endothelial cells: involvement in suppression of apoptosis. Circ Res 83: 334-342.

Dimmeler S, Aicher A, Vasa M, Mildner-Rihm C, Adler K, Tiemann M, Rütten H, Fichtlscherer S, Martin H, Zeiher AM (2001) HMG-CoA reductase inhibitors (statins) increase endothelial progenitor cells via the PI3-kinase/Akt pathway. J Clin Invest 108: 391-397.

Estany S, Palacio JR, Barnadas R, Sabes M, Iborra A, Martinez P (2007) Antioxidant activity of N-acetylcysteine, flavonoids and $\alpha$-tocopherol on endometrial cells in culture. J Reprod Immunol 75: 1-10.

Ferrara N (1999) Molecular and biological properties of vascular endothelial growth factor. J. Mol. Med 77: 527-543.

Finkenzeller G, Torio-Padron N, Momeni A, Mehlhorn AT, Stark GB (2007) In vitro angiogenesis properties of endothelial progenitor cells: a promising tool for vascularization of ex vivo engineered tissues. Tissue Eng 13: 1413-1420.

Fulton D, Gratton JP, McCabe TJ, Fontana J, Fujio Y, Walsh K, Franke TF, Papapetropoulos A, Sessa WC (1999) Regulation of endothelium-derived nitric oxide production by the protein kinase Akt. Nature 399: 597-601.

Imanishi T, Tsujioka H, Akasaka T (2008) Endothelial progenitor cells dysfunction and senescence: contribution to oxidative stress. Curr Cardiol Rev 4: 275-286.

Isner JM, Asahara T (1999) Angiogenesis and vasculogenesis as therapeutic strategies for postnatal neovascularization. J Clin Invest 103: 1231-1236.

Kalka C, Masuda H, Takahashi T, Kalka-Moll WM, Silver M, Kearney M, Li T, Isner JM, Asahara T (2000) Transplantation of ex vivo expanded endothelial progenitor cells for therapeutic neovascularization. Proc Natl Acad Sci 97: 3422-3427.

Kawasaki K, Watabe T, Sase H, Hirashima M, Koide H, Morishita Y, Yuki K, Sasaoka T, Suda T, Katsuki M, Miyazono K, Miyazawa K (2008) Ras signaling directs endothelial specification of VEGFR2+ vascular progenitor cells. J Cell Biol 181: 131-141.

Kureishi Y, Luo Z, Shiojima I, Bialik A, Fulton D, Lefer DJ, Sessa WC, Walsh K (2000) The HMG-CoA reductase inhibitor simvastatin activates the protein kinase Akt and promotes angiogenesis in normocholesterolemic animals. Nat Med 6: 1004-1010.

Lamant V, Mauco G, Braquet P, Chap H, Douste H, Douste-Blazy L (1987) Inhibition of the metabolism of platelet activating factor (PAF-acether) by three specific antagonists from Ginkgo biloba. Biochem Pharmacol 36: 2749-2752.

Lee MY, Huang JP, Chen YY, Aplin JD, Wu YH, Chen CY, Chen PC, Chen CP (2009) Angiogenesis in differentiated placental multipotent mesenchymal stromal cells is dependent on integrin $\alpha 5 \beta 1$. PLoS One 22: e6913.

Li R, Chen B, Wu W, Bao L, Li J, Qi R (2009) Ginkgolide B suppresses intercellular adhesion molecule-1 expression via blocking nuclear factor- $\kappa \mathrm{B}$ activation in human vascular endothelial cells stimulated by oxidized low-density lipoprotein. J Pharmacol Sci 3: 362-369.

Murohara T (2003) Angiogenesis and vasculogenesis for therapeutic neovascularization. Nagoya J Med Sci 66: $1-7$.

Nojima M, Maruyama R, Yasui H, Suzuki H, Maruyama Y, Tarasawa I, Sasaki Y, Asaoku H, Sakai H, Hayashi T, Mori M, Imai K, Tokino T, Ishida T, Toyota M, Shinomura Y (2009) Genomic screening for genes silenced by DNA methylation revealed an association between RASD1 inactivation and dexamethasone resistance in multiple myeloma. Clin Cancer Res 15: 4356-4364.

Peichev M, Naiyer AJ, Pereira D, Zhu Z, Lane WJ, Williams M, Oz MC, Hicklin DJ, Witte L, Moore MA, Rafii S (2000) Expression of VEGFR-2 and AC133 by circulating human $\mathrm{CD} 34(+)$ cells identifies a population of functional endothelial precursors. Blood 95: 952-958.

Rabbany SY, Heissig B, Hattori K, Rafii S (2003) Molecular pathways regulating mobilization of marrowderived stem cells for tissue revascularization. Trends Mol Med 9: 109-117. 
Sata M (2006) Role of circulating vascular progenitors in angiogenesis, vascular healing, and pulmonary hypertension: Lessons from animal models. Arterioscler Thromb Vasc Biol 26: 1008-1014.

Satoshi Murasawa, Takayuki Asahara (2005) Endothelial progenitor cells for vasculogenesis. Physiology 20: $136-142$.

Scheubel RJ, Zorn H, Silber RE, Kuss O, Morawietz H, Holtz J, Simm A (2003) Age-dependent depression in circulating endothelial progenitor cells in patients undergoing coronary artery bypass grafting. J Am Coll Cardiol 42: 2073-2080.

Shen J, Wang J, Zhao B, Hou J, Gao T, Xin W (1998) Effects of EGb 761 on nitric oxide and oxygen free radicals, myocardial damage and arrhythmia in ischemiareperfusion injury in vivo. Biochim Biophys Acta 1406: 228-236.

Spencer JP, Schroeter H, Kuhnle G, Srai SK, Tyrrell RM, Hahn U, Rice-Evans C (2001) Epicatechin and its in vivo metabolite, 3'-O-methyl epicatechin, protect human fibroblasts from oxidative-stress-induced cell death involving caspase-3 activation. Biochem J 354: 493-500.

Takahisa K, Satoshi S, Kengo M, Mutsuharu H, Yasuya I, Yasushi N, Kaichiro S, Yasuhiro M, Tomoya K, Haruo K, Takahito S, Miyoshi O, Toyoaki M (2010) The number and function of circulating CD34+CD133+ progenitor cells decreased in stable coronary artery disease but not in acute myocardial infarction. Heart Asia 2: 20-23.

Teather LA, Magnusson JE, Wurtman RJ (2002) Plateletactivating factor antagonists decrease the inflammatory nociceptive response in rats. Psychopharmacol (Berl) 163: 430-433.

Urbich C, Aicher A, Heeschen C, Dernbach E, Hofmann WK, Zeiher AM, Dimmeler S (2005) Soluble factors released by endothelial progenitor cells promote migration of endothelial cells and cardiac resident progenitor cells. J Mol Cell Cardiol 39: 733-742.

Walter DH, Rittig K, Bahlmann FH, Kirchmair R, Silver M, Murayama T (2002) Statin therapy accelerates reendothelialization: a novel effect involving mobilization and incorporation of bone marrow-derived endothelial progenitor cells. Circulation 105: 3017-3024.

Xu J, Liu X, Jiang Y, Chu L, Hao H, Liua Z, Verfaillie C, Zweier J, Gupta K, Liu Z (2008) MAPK/ERK signaling mediates VEGF-induced bone marrow stem cell differentiation into endothelial cell. J Cell Mol Med 12: 2395-2466.

Yoshikawa T, Naito Y, Kondo M (1999) Ginkgo biloba leaf extract: review of biological actions and clinical applications. Antioxid Redox Signal 1: 469-480.

Zhang WR, Hayashi T, Kitagawa H, Sasaki C, Sakai K, Warita H, Wang JM, Shiro Y, Uchida M, Abe K (2000) Protective effect of ginkgo extract on rat brain with transient middle cerebral artery occlusion. Neurol Res 22: 517-521.

Editor's Note: Since all questions/comments by the revewers were answered by text changes, there is no "Discussion with Reviewers" section. 